\title{
Review
}

\section{Potential Application of Bacteriocin Produced from Lactic Acid Bacteria}

\author{
Kaoutar El Issaoui ${ }^{1 *}$, Nadia Skali Senhaji ${ }^{1}$, Sanae Zinebi ${ }^{1}$, Rajae Zahli ${ }^{1}$, Imane Haoujar ${ }^{1}$, Nadia Amajoud ${ }^{1,2}$, Jamal Abrini ${ }^{1}$, \\ and El Ouardy Khay ${ }^{1}$ \\ ${ }^{1}$ Laboratory of Biology and Health, Department of Biology, Faculty of Sciences, BP: 2121. Abdelmalek Essaadi University, Tetouan 93002, \\ Morocco \\ ${ }^{2}$ Laboratory of Bacteriological Analysis of Water and Foodstuffs of the Urban Commune of Tetouan, Faculty of Sciences M'hannech 2, \\ Tetouan 93002, Morocco
}

Received: January 6, 2020 / Revised: March 10, 2020 / Accepted: March 11, 2020

Lactic acid bacteria prevent the contamination of food products by inhibiting proliferation of pathogenic bacteria. This is done mainly by the production of lactic acid and antimicrobial peptides (AMP ( $\left._{S}\right) k_{0 w n}$ as bacteriocins. The interest in these molecules resides in both their antimicrobial spectrum and safety for human health. The application of bacteriocins or producer strains has been considered to avoid the development of pathogenic bacteria, as most bacteriocins have significant inhibitory activity against food pathogens, such as Listeria monocytogenes. This article describes the classification, structure, mode of action, biosynthesis, and main applications of bacteriocins in different fields: agri-food, aquaculture, and medicine.

Keywords: Lactic acid bacteria, bacteriocins, food applications

\section{Introduction}

In general, fermented foods including milk and olives are considered less likely to cause foodborne infection or intoxication [1]. This reliability is due to the occurrence, during their fermentation, of different antimicrobial substances such as hydrogen peroxide, diacyls and bacteriocins produced by lactic acid bacteria, which prevent the proliferation of bacteria and pathogens in food [2,3].

During olive fermentation, lactic acid bacteria and yeasts are in competition for the same substrate $[4,5]$. Lactic cocci of the genera Pediococcus and Leuconostoc are the first to appear, followed by homofermentative strains such as Lactobacillus pentosus and Lactobacillus

\section{*Corresponding author}

Tel: +202-6-013-62038, Fax: +212-5-39-99-4500

E-mail: issaoui.kaoutar@hotmail.fr

(c) 2020, The Korean Society for Microbiology and Biotechnology plantarum. Various yeast species (which the most important are Pichia anomala, Pichia membranifaciens, Saccharomyces cerevisiae, Debaryomyces hansenii and Candida boidinii) can coexist with lactic acid bacteria throughout this process [6].

Lactic acid bacteria are considered among the most important microorganisms used in the food industry, be it in the fermentation of food or in the improvement of the taste and texture of fermented food products [7]. Bacteriocins are defined as protein-like molecules produced by antimicrobial bacteria (lactic acid bacteria), which act on other pathogenic bacteria by killing or inhibiting their growth [8]. Studies have described their production by lactic acid bacteria isolated from fermented olives [9-11].

Bacteriocins have traditionally been used as food preservatives, added or produced by bacterial cultures during fermentation. Several applications for this group of sub- 
stances have been studied such as food preservation, cancer, contraception, oral care, systemic infections and skin care [12].

\section{Lactic acid bacteria}

The term lactic acid bacteria (LAB) was gradually accepted in the early 20th century [13]. Other terms such as "milk acidifying bacteria" and "producing lactic acid" had already been used for the same bacteria, causing slight confusion. This ended with the publication of a monograph on lactic acid bacteria written by [14].

LAB are asporulated, generally non-motile and Gram positive aerotolerant rods and cocci. They are often unable to synthesize cytochromes and porphyrins, components of respiratory chains $[15,16]$. Because they don't use oxygen during energy production, lactic acid bacteria readily grow under anaerobic conditions, but they can also grow in the presence of oxygen.

Because they have complex nutritional requirements for amino acids, vitamins, peptides, salts, fatty acids and carbohydrates, lactic acid bacteria are present everywhere in nature and they are generally associated with nutrient-rich habitats such as different food products (milk, beverages, meat products, plant products...). They also exist in the digestive system of humans, they belong to the normal flora of the gut, the mouth and the vagina [17].

Lactic acid bacteria are also characterized by the GC content of their DNA, this content varies between 33 and $54 \%$, which classifies them among bacteria with a low percentage of GC [18].

\section{Classification}

Lactic acid bacteria are a relatively close group of bacteria that share similar morphological, metabolic and physiological characteristics.

According to Orla-Jensen [14], their classification into different genera was based initially on the morphology: Bacilli (Lactobacillus and Carnobacterium), Cocci (the other genera). After, other characteristics were used for their classification such as glucose fermentation mode (homofermentative pathway where the majority of sugar is converted to lactic acid; or heterofermentative pathway in which bacteria produce in addition to lactic acid, ethanol and acetic acid), growth at different temperatures and at high saline concentrations, acid tolerance or alkaline and the configuration of lactic acid. For some newly described genera, additional characteristics such as fatty acid composition and motility are used in the classification [19].

Currently, lactic acid bacteria include various bacterial genera including Lactobacillus, Lactococcus, Leuconostoc, Pediococcus, Streptococcus, Aerococcus, Carnobacterium, Enterococcus, Oenococcus, Tetragenococcus, Vagococcus and Weissella [20-22], with Lactobacillus being the largest genus, with more than 241 abundant species (http:// www.bacterio.net/lactobacillus.html). Bifidobacterium bacteria are widely used and widespread in the dairy industry, but they can't be considered typical as lactic acid bacteria [23].

\section{General metabolism of lactic acid bacteria}

Lactic acid bacteria generate ATP by fermentation of hydrocarbons coupled with phosphorylation at the substrate level. The two major pathways of hexose metabolism are the glycolytic pathway (Embden-Meyerhof-Parnas pathway), of which lactic acid is generally the main end product, homofermental metabolism, (for L. latis more than $90 \%$ of sugar substrate is converted into lactic acid); and the phosphoketolase pathway in which other end products such as acetic acid, propionic acid, ethanol and $\mathrm{CO}_{2}$ are formed in addition to lactic acid (heterofermental metabolism) [24].

\section{Homofermentative pathway}

Homolactic bacteria transform almost all the sugar substracte (especially glucose) into lactic acid. This fermentation route comprises a first phase of glycolysis leading to the formation of pyruvate. The latter is reduced to lactic acid and serves as the terminal electron acceptor (Fig. 1) [21].

The glycolysis occurring in Streptococcus, Pediococcus and some lactobacilli is characterized by the dissociation of fructose 1,6-bisphosphate, using aldolase, into two fragments of triose phosphate which are subsequently converted to lactate [25].

\section{Heterofermentative pathway}

Hetero-fermentative bacteria use the phosphoketolase pathway in carbohydrate metabolism. The energy efficiency of the pathway is a single ATP per metabolized glucose. In general, most lactic acid bacteria are charac- 
(a)

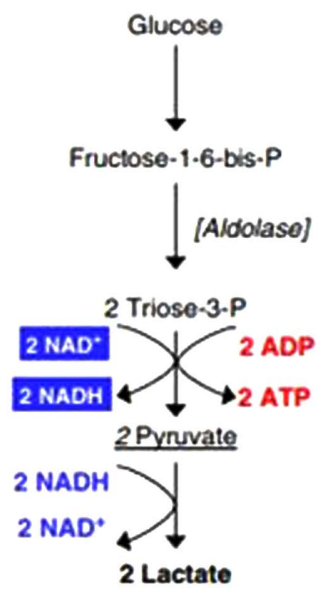

(b)

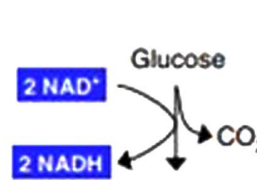

Xylulose-5.P

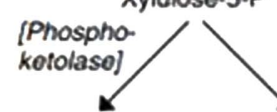

Triose-3.P Acotyl.P

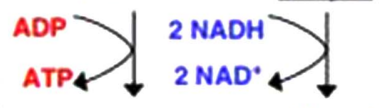

Pynuvate

$\downarrow$

Ethanol

Lactate (c)

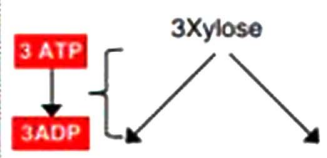

Riboso-5.P + 2 Xyluloso-5.P

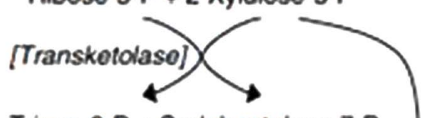

Triose-3.P + Seduheptulose-7.P

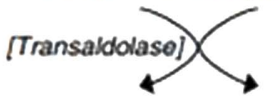

Fructose-6.P + Erythrose-4.P

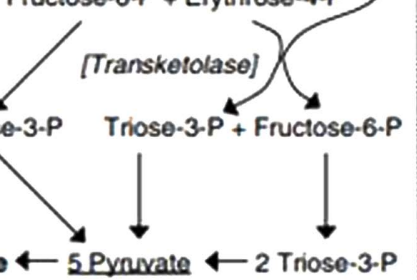

(d)

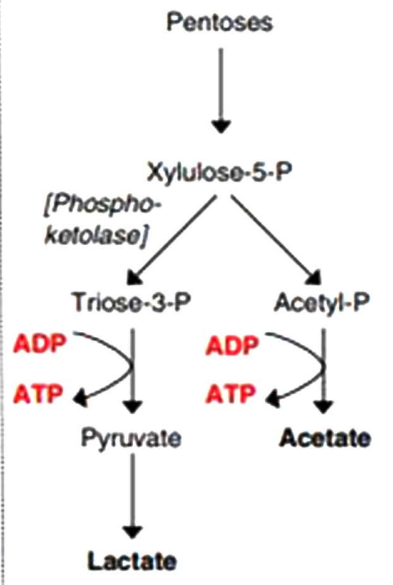

Fig. 1. Fermentation of carbohydrates by lactic acid bacteria, (a) Homofermentative metabolism of hexoses via the EmdenMeyerhof-Parnas pathway; (b) Hetero-fermentative metabolism of hexoses via the phosphoketolase pathway; (c) Homofermentative metabolism of pentoses via the pentose phosphate pathway; and (d) Heterofermentative metabolism of pentoses by the phosphoketolase pathway [24].

terized by a slow growth rate in the case where glucose is the only source of carbon [26].

Hetero-fermentative bacteria generally convert pyruvate from hexoses and pentoses to lactate. However, alternative end products of pyruvate are observed in the metabolism of citrate and pyruvate in Leuconostoc spp. and Oenococcus oeni.

\section{Probiotic effects of lactic acid bacteria}

The term "probiotic" is made up of two Greek words: "pro" and "bios", and refers to "all living microbial preparations used as food additives and which have a beneficial effect on the host by improving digestion and intestinal hygiene."

Another definition of probiotics is that they are living microorganisms when administered in adequate amounts, confer beneficial effects on the host [27]. They produce a wide variety of antibacterial molecules, of which nisin is the most used as a food preservative. They are among the most promising alternatives of antibiotics. Their application is widely accepted today both in the agri-food sector and in aquaculture [28, 29].

The effects of probiotics are specific to the strain. They can improve health performance by maintaining intestinal microbial balance, inhibiting pathogens [30], strengthening the intestinal barrier and modulating the immune system [31]. Many strains have been described as probiotics (Table 1), they are often lactic acid bacteria or yeasts introduced into the diet in the form of fermented milk

Table 1. The main species of probiotics [32].

\begin{tabular}{|c|c|c|}
\hline \multicolumn{3}{|c|}{ Probiotic species } \\
\hline $\begin{array}{l}\text { Lactobacillus } \\
\text { species }\end{array}$ & $\begin{array}{c}\text { Bifidobobacterium } \\
\text { species }\end{array}$ & Other species \\
\hline $\begin{array}{l}\text { L. acidophilus, } \\
\text { L. brevis, } \\
\text { L. casei, } \\
\text { L. crispatus, } \\
\text { L. fermentum, } \\
\text { L. gasseri, } \\
\text { L. helveticus, } \\
\text { L. johnsonii, } \\
\text { L. lactis, } \\
\text { L. paracasei, } \\
\text { L. plantarum, } \\
\text { L. reuteri, } \\
\text { L. rhamnosus, } \\
\text { L. salivarius. }\end{array}$ & $\begin{array}{l}\text { B. adolescentis, } \\
\text { B. animalis, } \\
\text { B. bifidum, } \\
\text { B. breve, } \\
\text { B. infantis, } \\
\text { B. lactis, } \\
\text { B. longum. }\end{array}$ & $\begin{array}{l}\text { Enterococcus faecium, } \\
\text { E. faecalis, } \\
\text { Streptococcus lactis, } \\
\text { S. thermophilus, } \\
\text { Lactococcus lactis, } \\
\text { Bacillus cereus, } \\
\text { B. subtilis, } \\
\text { Escherichia coli Nissle 1917, } \\
\text { Saccharomyces boulardii, } \\
\text { S. cerevisiae. }\end{array}$ \\
\hline
\end{tabular}


products or dietary supplements [32]. Lactic probiotic strains belong mainly to the genera Lactobacillus spp. [33], Bifidobacterium spp. and Enterococcus spp. [34, $35]$.

\section{Bacteriocins}

Bacteriocins are defined as antimicrobial peptides of about 30 to 60 amino acids, synthesized ribosomally and forming stable amphiphilic helices at $100^{\circ} \mathrm{C}$ for $10 \mathrm{~min}$. They have traditionally been used as food preservatives, added or produced by starter cultures during fermentation.

They were first identified as a thermolabile product called colicin, present in Escherichia coli $V$ cultures and toxic to $E$. coli $S$. [36]. Since then, bacteriocins have been found in all major bacterial lineages, the vast majority of which are produced by Gram-positive bacteria [37].

The bacteriocins produced by lactic acid bacteria have attracted increasing attention because they are active in a nanomolar range and have no toxicity. They are defined as protein-like molecules produced by the antibacterial bacteria called lactic acid bacteria, which cause antibacterial activity, killing or inhibiting the growth of other bacteria including pathogenic bacteria such as Listeria monocytogenes [38], without alteration of producing bacteria.

Several characteristics are common for bacteriocins such as heat and acid stability, resistance to proteases, a bactericidal or bacteriostatic effect and prolonged activity [39].

Its self-protection is mainly due to the synthesis of specific immunity proteins encoded by the bacteriocin operon [40].

In addition to the synthetic route and the concentration required for inhibitory activity, bacteriocins differ from antibiotics in that they have a relatively narrow spectrum of action and that the antibacterial activity is directed against taxonomically related strains of the producing strain [41]. These molecules have been found in all major bacterial lineages, and according to [42], 99\% of bacteria can make at least one bacteriocin.

\section{Classification of bacteriocins produced by lactic acid bac- teria}

Bacteriocins were classified according to primary structures, molecular weight, post-translational properties and genetic characteristics. According to Klaenhammer (1993), four classes of bacteriocins have been distinguished. Subsequently, different classification schemes for bacteriocins have been proposed, taking into account new subclasses, based on the mechanism of biosynthesis and the antibacterial activity of the molecules [43, 44].

\section{Lantibiotics}

Class I bacteriocins or lantibiotics are peptidic inhibitors with molecular mass of less than $5 \mathrm{kDa}$, produced by Gram-positive bacteria [45], with nisin and lactocin as the most widely recognized. They are characterized by post-translational modifications, resulting in the formation of a mixture of atypical amino acids such as lanthionine, methyllanthionine, dehydroalanine and dehydrobutyrine [45, 46].

The lantibiotics are divided into two subgroups, $\mathrm{A}$ and $\mathrm{B}$, differing according to their structural characteristics and their mode of inhibition [47]. The type A lantibiotics, or lantipeptides, comprise elongated hydrophobic cationic peptides containing up to 34 amino acids, they act on the target cell by depolarization of the cytoplasmic membrane [48]. Type B lantibiotics include globular peptides that are negatively charged or without net charge, are smaller than type A, and contain up to 19 amino acids [49].

\section{Class II bacteriocins}

Class II bacteriocins or non-lantibiotics are relatively small molecules $(<10 \mathrm{kDa})$ ranging in size from 30 to 60 amino acids. They are thermostable and do not undergo post-translational modification.

This class comprises the largest subgroup of bacteriocins: class IIa (pediocin-like), characterized by a close activity against Listeria monocytogenes [50], class IIb, two-peptide bacteriocins, whose activity depends on the synergy between two different peptides. They generally have an action spectrum that inhibits a wide range of Gram-positive bacteria, they form pores in the membrane of the target cells [51] ; class IIc which groups circular bacteriocins and class IId which includes all other bacteriocins [52].

\section{Class III Bacteriocins}

This class includes bacteriocins which have a high molecular weight $(>30 \mathrm{kDa})$. They are thermolabile pro- 
teins that act in a different way from other classes of bacteriocins. Colicin is the most characteristic of this class [53]. It generally contains three domains, including receptor binding, translocation and the lethal domain [54].

Another proposed additional class (class VI) is defined as complex bacteriocins containing lipid or carbohydrate moieties. Little is known about the structure and function of this class, which includes leuconocin S [55] and lactocin 27 as an example [56].

\section{Bacteriocins production}

The production of bacteriocins by lactic acid bacteria is influenced mainly by the temperature, the $\mathrm{pH}$, the composition of the medium [57, 58], and by the producing strain, which can produce proteases that act by degradation of bacteriocins [59]. It is usually done during the exponential phase and reaches a maximum threshold during the stationary phase of growth [60-63]. The produced bacteriocins can then be degraded by the proteases produced by the lactic acid bacterium [59] or adsorbed on its surface, which leads to a decrease in the concentration of bacteriocins in the culture [64].

In general, the production of bacteriocins by lactic acid bacteria begins with the formation of a very little or nonbiologically active pre-peptide, which later undergoes post-translational modifications to lead to the active peptide [64]. This pre-peptide matured during or immediately after its secretion in the extracellular medium (Fig. 2) [65]. The mechanism of production of bacteriocins is often regulated by a system called Quorum Sensing, a mechanism that allows certain genes to be expressed according to the density of the bacterial population [66].

Two essential constituents are involved in the secretion of bacteriocin: the signal peptide or leader and the transporter, the first allows the secretion of bacteriocin in the external medium, in addition it protects the bacterium against the action of its own bacteriocin [67]. The second, a carrier formed by the products of two genes: $\mathrm{ABC}$ transporter gene, associated with a gene encoding an accessory protein [68].

\section{Mode of action}

The bacteriocins often act on the target cells in two steps: adsorption of the bacteriocin at the cell surface, followed by the formation of pores on the plasma membrane of the target cell [69], causing a permeability of

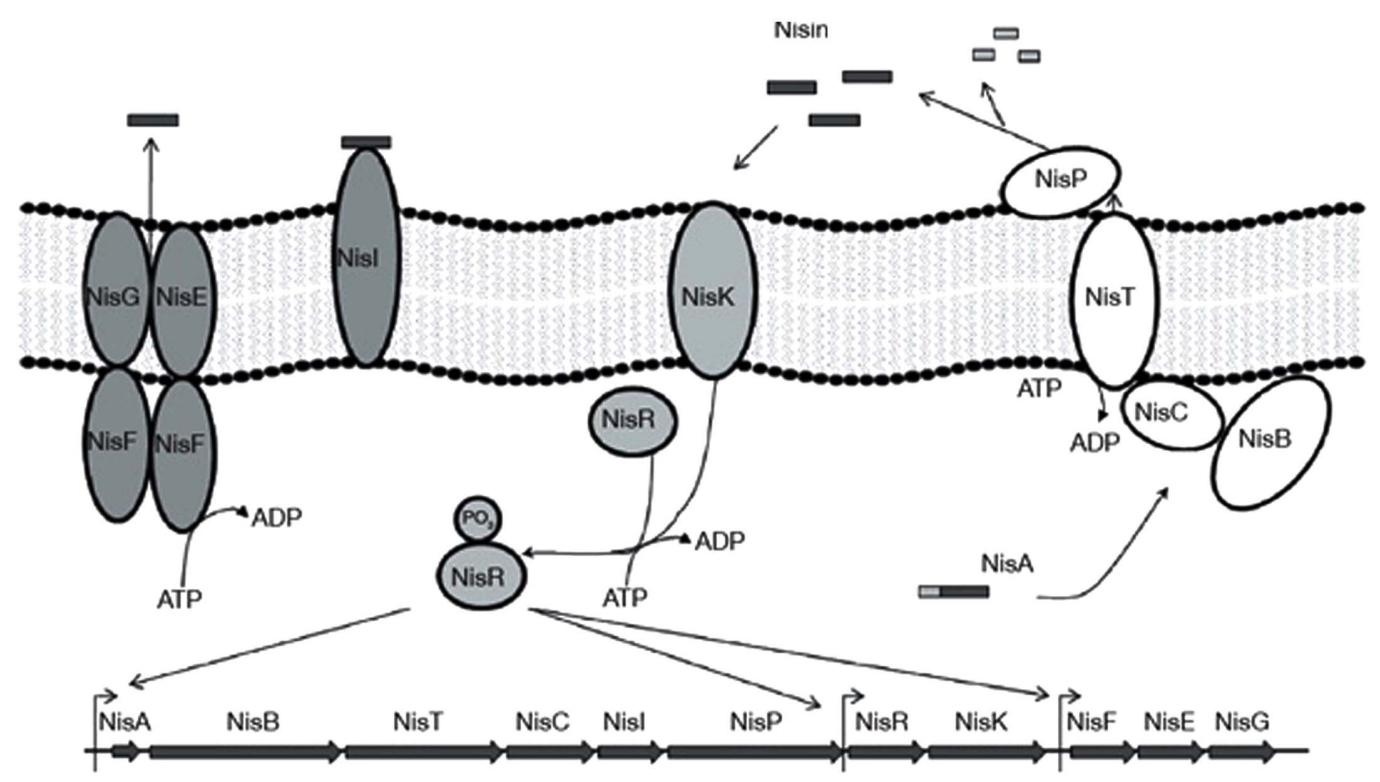

Fig. 2. Regulation of biosynthesis, post-translational modification and auto-immunity of nisin. After the prepeptide (NisA) undergoes modifications based on dehydration using (NisB), cyclization by (NisC), translocation via the ABC transporter (NisT), cleavage by protease (NisK); the response regulator (NisR) is phosphorylated, inducing the activation of transcription of nisin synthesis genes. The cell's autoimmunity to the bacteriocin produced is conferred by the lipoprotein immunity (Nisl) and the ABC transporter (NisG, NisE, NisF) [74]. 
this one and thus cell death [70].

Their mechanisms of action on the target cell are varied, and can be divided into three types: bacteriostatic action that leads to slowing down or stopping growth, without cell death, bactericidal action during which bacteria die while keeping their physical integrity (no cell lysis) and bacteriolytic action that leads to dissolution of the bacterial cell [71].

Several lantibiotics and certain class II bacteriocins have a dual mode of action: either they bind to lipid II, an intermediate in the biosynthetic mechanism of the peptidoglycan of the bacterial cell, and therefore prevent the correct synthesis of the wall, this leads to cell death [72]; or they use lipid II as an anchoring molecule to facilitate pore formation [73], leading to the dissipation of the proton motive force and the leakage of intracellular compounds to the outside of susceptible bacteria, and ultimately cell death [70, 74].

In addition, class III which comprises bacteriocins with a high molecular weight, the mechanism of action differs totally from other bacteriocins, some act by hydrolysis of peptide bonds peptidoglycan sensitive cells $[75,66]$.

\section{Applications}

In recent decades, bacteriocins, given their safety, have been used as alternatives to antibiotics and recognized several applications in the food industry to extend the shelf life of food, and in medicine in the prevention and/or treatment of infections, due to bacteria that have become resistant to conventional treatments [76] and in the treatment of malignant cancers.

So far, two bacteriocins, nisin and pediocin PA-1 have been marketed as food additives. In addition, enterocin AS-48 [77] and lacticin 3147 [78], for example, have also been identified as bacteriocins produced from lactic acid bacteria containing biocidal properties of food preservation.

Bacteriocins can be used in various forms: purified; semi-purified as a food preservative, such as nisin [52]; or as a preparation bacterial strain whose bacteriocinogenic strains can be directly inoculated into foods as starter, auxiliary or protective crops [79]. Recently, bacteriocins have been incorporated into packaging films to control foodborne pathogenic bacteria.

\section{Bacteriocins application in food processing}

The bio-preservation of foods by bacteriocins has been the most studied for a long time. It consists of an increase in the life span and an improvement of food safety through the use of lactic acid bacteria and/or their metabolites, which act by reducing the food contamination by pathogens such as Listeria monocytogenes [8082]. Several bacteriocins produced by lactic acid bacteria, such as Lactobacillus plantarum, Pediococcus acidilactici and Enterococcus faecalis, have been investigated for their antimicrobial effect against pathogenic bacteria.

Thus, many studies have indicated the application of bacteriocins in dairy products, by the addition of lactic acid bacteria as protective cultures that develop and produce bacteriocins during the manufacture and storage of dairy products [83]. Other studies have also focused on the selection and development of bacteriocinogenic cultures as agents inducing cell lysis to improve cheese maturation [84] and to prevent late infections of the food [85].

Nisin produced by Lactococcus lactis was the first antibacterial peptide used in the agri-food industry [86]. It is a commercial bacteriocin used as a food preservative marketed under the name of Nisaplin ${ }^{\mathrm{TM}}$. A study conducted by [87] suggested that food nisin has a mode of action similar to that of salinomycin and could be considered a dietary supplement for broilers.

In another study of [88] were able to purify a bacteriocin enterocin RM6 from Enterococcus faecalis, active against Gram-positive bacteria, including Listeria monocytogenes, Bacillus cereus and methicillin-resistant Staphylococcus aureus (MRSA). This bacteriocin caused a reduction of 4 logarithms of the $L$. monocytogenes population inoculated at a concentration of $80 \mathrm{AU} / \mathrm{ml}$, in a cheese for at least 30 minutes of treatment. A new study conducted by [82] reported a reduction in the concentration of $L$. monocytogenes by adding three strains of Lactococcus lactis producing nisin A to fresh cheese.

Recently several studies have been able to present the positive effect of the use of bacteriocins in food packaging films [89, 90]. In fact, this type of antimicrobial packaging increases the shelf life, safety and quality of many food products by reducing microbial growth in non-sterile foods and minimizing the risk of post-contamination of processed products [91].

Several methods have been followed in incorporating 
bacteriocins into packaging films, one of which incorporates bacteriocin directly into the polymers, such as the incorporation of nisin into the biodegradable protein films [92].

Another method is to adsorb bacteriocins on the surfaces of the polymer: methylcellulose nisin coatings for polyethylene films for use on poultry meat [93].

\section{Bacteriocins in aquacultures}

The use of bacteriocins, or their producing strains as probiotics [94, 95], and animals [87] has been well documented. Recently, supplementation with probiotics in aquaculture has been reported to improve growth performance, immune responses and disease resistance.

Various kinds of lactic acid bacteria have been studied with regard to their immunomodulatory effects on many different species of fish: Lactobacillus [96], Lactococcus [97], Enterococcus [98]; although the majority of studies have used a specific strain of live lactic acid bacteria. Some studies have been conducted with their inactivated form of LAB.

Numerous modes of lactic acid bacteria administration have been studied: treatment of fish by intraperitoneal injection [99], immersion of fish in a bath containing lactic acid bacteria [98, 100], administration of lactic acid bacteria in the regular diets of fish ... Some studies have shown that the administration of dietary probiotics has better immunostimulatory effects.

The effect of two probiotic strains of Lactobacillus plantarum T8 and T13 on the growth and survival of the white-legged shrimp, L. vannamei, was tested by [97]). It has been shown that both $\mathrm{T} 8$ and $\mathrm{T} 13$ are significantly reduced in the incidence of $10^{5}$ or $10^{6} \mathrm{CFU} / \mathrm{ml}$ after $48 \mathrm{~h}$ or $24 \mathrm{~h}$ of infection, respectively.

\section{Use of bacteriocins in medicine}

Increasing the number of multi-resistant pathogens has become a serious problem and it is increasingly important to find or develop a new generation of antimicrobial agents. Studies are currently oriented towards finding new substances and antibacterials as natural therapy agents that are alternative to antibiotics [101].

Lactic acid bacteria or their bacteriocins being protein inhibitors of a non-toxic nature, with a high specificity of action and a potential inhibitory effect on multidrugresistant pathogens [102], have increased the interest of many scientists to carry out work on their applications in the medical field.

They have beneficial effects on the host by imparting a balance of intestinal microflora, and also playing an important role in the maturation of the immune system 97. Various studies have demonstrated the preventive as well as curative role of these bacteria on several types of diarrhea [103-105] demonstrated the effect of fermented milk by different lactic strains of Lactobacillus murinus CRL1695, Lactobacillus mucosae CRL1696, Lactobacillus johnsonii CRL1693 and Lactobacillus salivarius CRL1702 on the incidence of diarrhea, animal performance, nutritional, microbiological, and hematologic parameters in calves. The study indicated a decrease in the prevalence of diarrhea and mortality in animals with significant weight gain. Other research has cited the role of lactic acid bacteria in regulating the immune system [106].

The safety of bacteriocins, and their mode of action which differs from those of conventional antibiotics, have allowed their use as an alternative to antibiotics in the prevention and/or treatment of various infections: cutaneous [107], respiratory [108], systemic [109] and/or urogenital [110] as well as contraceptive agents.

\section{Combination of bacteriocins with other antibacterial fac- tors/molecules}

The combination of bacteriocins with other antimicrobial agents is an approach that aims to improve the protective action. The antimicrobial agents may be of physical type such as heat treatments and high-pressure or chemical-type treatments such as some additives (organic acids, nitrite, sodium chloride, ethanol, essential oils, etc.,)

A large group of antimicrobial peptides that belong to class IIa bacteriocins can be used in medicine with antibiotics in the treatment of infectious diseases or as antiviral agents. These peptides have inhibitory activity against harmful and pathogenic Gram-positive bacteria such as Bacillus cereus, Clostridium perfringens, Staphylococcus aureus and Listeria monocytogenes [126].

Nisin has been the subject of several association studies with antimicrobial molecules to inhibit foodborne pathogens. A concentration of 6400 IU nisin in combination with green tea extract (GTE) or in combination with Grape Seed Extract (GSE) resulted in effective cell dam- 
Table 2. Recent and main applications of bacteriocins in different fields.

\begin{tabular}{|c|c|c|c|c|c|c|c|c|}
\hline Bacteriocin & Producer & Origin & Concentration & Product & Target & Properties & Country & Reference \\
\hline $\begin{array}{l}\text { Bacteriocin } \\
\text { FAIR-E } 198\end{array}$ & $\begin{array}{l}\text { Enterococcus } \\
\text { faecium } \\
\text { FAIR-E } 198\end{array}$ & Feta cheese & $100 \mathrm{UA} \mathrm{m}^{-1}$ & Cheese & & $\begin{array}{l}\text { When enterocin was treated with rennet at a } \\
\text { concentration of } 0.020 \mathrm{mg} \mathrm{ml}^{-1} \text { no activity } \\
\text { was detected after } 6 \mathrm{~h} \text { of incubation. On the } \\
\text { contrary, in the presence of } 0.002 \mathrm{mg} \mathrm{ml}^{-1} \text { of } \\
\text { rennet, the enterocin activity remained intact } \\
\text { after } 6 \mathrm{~h} \text { of incubation. }\end{array}$ & Greece & [83] \\
\hline Sakacin G & $\begin{array}{l}\text { Lactobacillus } \\
\text { curvatus } \\
\text { ACU-1 }\end{array}$ & $\begin{array}{c}\text { Artisanal dry } \\
\text { sausages }\end{array}$ & $800 \mathrm{UA} \mathrm{ml}^{-1}$ & $\begin{array}{l}\text { Meats } \\
\text { products }\end{array}$ & $\begin{array}{l}\text { Listeria innocua } \\
\text { ATCC } 33090 \\
\text { and Listeria } \\
\text { monocytogenes } \\
\quad 01 / 155\end{array}$ & $\begin{array}{l}\text { The addition of } L b \text {. Curvatus ACU- } 1 \text { CFS at the } \\
\text { exponential phase of growth of } L \text {. Innocua } \\
\text { ATCC } 33090 \text { and } L \text {. Monocytogenes } 01 / 155 \\
\text { cell suspensions resulted in a decrease in } \\
\text { optical density for both bacteria. }\end{array}$ & Argentina & [111] \\
\hline $\begin{array}{l}\text { Bacteriocin } \\
\text { RC20975 }\end{array}$ & $\begin{array}{l}\text { Lactobacillus } \\
\text { rhamnosus }\end{array}$ & $\begin{array}{l}\text { Center of } \\
\text { Industrial } \\
\text { Culture } \\
\text { Collection, } \\
\text { China }\end{array}$ & $20 \mathrm{mg} \mathrm{ml}^{-1}$ & $\begin{array}{l}\text { Apple } \\
\text { juice }\end{array}$ & $\begin{array}{l}\text { Alicyclobacillus } \\
\text { acidoterrestris }\end{array}$ & $\begin{array}{l}\text { Bacteriocin RC20975 as found to have a } \\
\text { good effect on killing } A \text {. Acidoterrestris in } \\
\text { apple juice. The bacteriocin influences the } \\
\text { reduction of spore temperature of } A \text {. Acido- } \\
\text { terrestris in the apple of apple. }\end{array}$ & China & [94] \\
\hline $\begin{array}{l}\text { Pentocin } \\
31-1\end{array}$ & $\begin{array}{l}\text { Lactobacillus } \\
\text { pentosus } \\
31-1\end{array}$ & $\begin{array}{l}\text { Xuan-wei } \\
\text { ham }\end{array}$ & $80 \mathrm{UA} \mathrm{ml}^{-1}$ & Pork meat & - & $\begin{array}{l}80 \mathrm{AU} / \mathrm{ml} \text { pentocin could extend the shelf life } \\
\text { to } 15 \text { days and the meat showed good sen- } \\
\text { sory characteristics. These results suggest the } \\
\text { potential of pentocin } 31-1 \text { as a biopreserva- } \\
\text { tive in tray-packaged chilled pork storage. }\end{array}$ & China & [112] \\
\hline $\begin{array}{l}\text { Enterocin } \\
\text { RM6 }\end{array}$ & $\begin{array}{l}\text { Enterococcus } \\
\text { faecalis } \\
\text { OSY-RM6 }\end{array}$ & $\begin{array}{l}\text { Raw } \\
\text { milk }\end{array}$ & $80 \mathrm{UA} \mathrm{ml}^{-1}$ & $\begin{array}{l}\text { Cottage } \\
\text { cheese }\end{array}$ & L. monocytogenes & $\begin{array}{l}\text { Enterocin } \mathrm{RM} 6 \text { with concentration in cottage } \\
\text { cheese, } 80 \mathrm{AU} / \mathrm{ml} \text {, caused a } 4 \text {-log reduction in } \\
\text { population of } L \text {. Monocytogenes inoculated } \\
\text { in cottage cheese within } 30 \text { min of treat- } \\
\text { ment. }\end{array}$ & USA & {$[88]$} \\
\hline Nisin & $\begin{array}{l}\text { Lactococcus } \\
\text { lactis subsp. } \\
\text { Lactis IFO12007 }\end{array}$ & $\begin{array}{l}\text { Non } \\
\text { mentioned }\end{array}$ & $1,28.10^{5} \cup A \mathrm{ml}^{-1}$ & $\begin{array}{l}\text { Fer- } \\
\text { mented } \\
\text { soybeans }\end{array}$ & Bacillus subtilis & $\begin{array}{l}\text { Lc. Lactis produced high nisin activity } \\
(1.28 \times 105 \mathrm{AU} / \mathrm{g}) \text { in cooked soybean, result- } \\
\text { ing in the complete growth inhibition of } B \text {. } \\
\text { Subtilis, which had been inoculated at the } \\
\text { beginning of the koji fermentation, through- } \\
\text { out the process of miso production. }\end{array}$ & Japan & [113] \\
\hline $\begin{array}{l}\text { Plantaricin } \\
\text { IIA-1A5 }\end{array}$ & $\begin{array}{l}\text { Lactobacillus } \\
\text { plantarum } \\
\text { IIA-1A5 }\end{array}$ & $\begin{array}{c}\text { Saucisse de } \\
\text { boeuf }\end{array}$ & $0,3 \%$ & $\begin{array}{c}\text { Beef } \\
\text { sausage }\end{array}$ & $\begin{array}{l}\text { Staphylococcus } \\
\text { aureus and } \\
\text { Escherichia coli }\end{array}$ & $\begin{array}{l}\text { The results showed that the presence of bac- } \\
\text { teriocin in the sausages inhibited the growth } \\
\text { of pathogenic Staphylococcus aureus and } \\
\text { Escherichia coli bacteria until day } 6 \text {, which } \\
\text { was better than the inhibition observed in } \\
\text { the presence of nitrite. }\end{array}$ & Indonisia & [114] \\
\hline $\begin{array}{l}\text { Fermenticin } \\
\text { HV6b }\end{array}$ & $\begin{array}{l}\text { Lactobacillus } \\
\text { fermentum } \\
\text { HV6b MTCC } \\
10770\end{array}$ & $\begin{array}{l}\text { Vaginal } \\
\text { humain } \\
\text { ecosystem }\end{array}$ & $50-200 \mu \mathrm{g} \mathrm{ml}^{-1}$ & $\begin{array}{l}\text { Bacterial } \\
\text { vaginosis }\end{array}$ & $\begin{array}{l}\text { Bacteroides, } \\
\text { Gardnerella } \\
\text { vaginalis, } \\
\text { Mobiluncus, } \\
\text { staphylococci, and } \\
\text { streptococci }\end{array}$ & $\begin{array}{l}\text { Fermenticin HV6b shows growth inhibition } \\
\text { of a wide range of opportunistic pathogen- } \\
\text { sof humans, for example, Bacteroides, Gard- } \\
\text { nerella vaginalis, Mobiluncus, staphylococci, } \\
\text { and streptococci, associated with bacterial } \\
\text { vaginosis in humans. }\end{array}$ & India & [115] \\
\hline $\begin{array}{l}\text { Bacteriocine } \\
\text { CR1T5 }\end{array}$ & $\begin{array}{l}\text { Lactobacillus } \\
\text { plantarum } \\
\text { CR1T5 }\end{array}$ & $\begin{array}{c}\text { Non } \\
\text { mentioned }\end{array}$ & $\begin{array}{l}3,79.10^{9} \\
\text { cfu g }^{-1}\end{array}$ & $\begin{array}{l}\text { Pangasius } \\
\text { catfish }\end{array}$ & - & $\begin{array}{l}\text { Dietary supplementation of PE and } L \text {. Planta- } \\
\text { rum stimulated growth, immunity and dis- } \\
\text { ease resistance of the Pangasius bocourti. }\end{array}$ & Thailand & [116] \\
\hline $\begin{array}{l}\text { Bacteriocin } \\
\text { DY4-2 }\end{array}$ & $\begin{array}{l}\text { Lactobacillus } \\
\text { plantarum } \\
\text { DY4-2 }\end{array}$ & $\begin{array}{l}\text { Shrimp } \\
\text { (Trichiurus lep- } \\
\text { turus) }\end{array}$ & $4 \mathrm{mg} \mathrm{ml}^{-1}$ & $\begin{array}{l}\text { Turbot } \\
\text { fillets }\end{array}$ & $\begin{array}{c}\text { Pseudomonas } \\
\text { Fluorescens }\end{array}$ & $\begin{array}{l}\text { The addition of partially purified bacteriocin } \\
\text { DY } 4-2 \text { in turbot fillets reduced the number of } \\
\text { Pseudomonas Fluorescens by } 2.7 \text { log units at } 4 \\
{ }^{\circ} \mathrm{C} \text { storage for } 12 \text { days. }\end{array}$ & China & [117] \\
\hline Pediocin A & $\begin{array}{c}\text { Pediococcus } \\
\text { pentosaceus } \\
\text { FBB61 }\end{array}$ & Cucumbre & $80 \mathrm{UA} \mathrm{g}^{-1}$ & Broilers & $\begin{array}{l}\text { Clostridium } \\
\text { Perfringens }\end{array}$ & $\begin{array}{l}\text { Diet supplementation with pediocin A } \\
\text { improved broiler growth performance } \\
\text { during the challenge with Clostridium Perfrin- } \\
\text { gens and tended to restore the ADG deple- } \\
\text { tion during the } 42-\mathrm{d} \text { period. }\end{array}$ & Italy & [118] \\
\hline
\end{tabular}


Table 2. Continued.

\begin{tabular}{|c|c|c|c|c|c|c|c|c|}
\hline Bacteriocin & Producer & Origin & Concentration & Product & Target & Properties & Country & Reference \\
\hline $\begin{array}{l}\text { Bactériocine } \\
\text { NC0209951 }\end{array}$ & $\begin{array}{c}\text { Enterococcus } \\
\text { casseliflavus- } \\
\text { nc0209951 }\end{array}$ & $\begin{array}{l}\text { Rainbow } \\
\text { trout gut }\end{array}$ & $\begin{array}{l}10^{7} \mathrm{cfu} \mathrm{g}^{-1} \\
10^{8} \mathrm{cfu} \mathrm{g}^{-1} \\
10^{9} \mathrm{cfu} \mathrm{g}^{-1}\end{array}$ & Rainbow & - & $\begin{array}{l}\text { Enterococcus casseliflavus is indicated by its } \\
\text { capability in improving growth performance } \\
\text { and modulating the innate defenses of the } \\
\text { host (rainbow). }\end{array}$ & Iran & [119] \\
\hline $\begin{array}{l}\text { Fermencin } \\
\text { SA715 }\end{array}$ & $\begin{array}{l}\text { Lactobacillus } \\
\text { fermentum } \\
\text { GA715 }\end{array}$ & $\begin{array}{l}\text { Goat's } \\
\text { milk }\end{array}$ & $2.0714 \mathrm{mM}$ & Banana & $\begin{array}{l}\text { Streptococcus spp., } \\
\text { Enterococcus spp,. } \\
\text { Escherichia coli, } \\
\text { Listeria monocyto- } \\
\text { genes, and others }\end{array}$ & $\begin{array}{l}\text { Fermencin SA715 doubled the shelf life and } \\
\text { improved the microbiological safety of fresh } \\
\text { banana. }\end{array}$ & Malaysia & [95] \\
\hline $\begin{array}{l}\text { Bacteriocin } \\
\text { DF04Mi }\end{array}$ & $\begin{array}{l}\text { Lactococcus } \\
\text { lactis DF04Mi }\end{array}$ & $\begin{array}{l}\text { Goat's } \\
\text { milk }\end{array}$ & $10^{6} \mathrm{cfu} \mathrm{m}^{-1}$ & Cheese & $\begin{array}{c}\text { Listeria } \\
\text { monocytogenes }\end{array}$ & $\begin{array}{l}\text { Addition of nisin }(12.5 \mathrm{mg} / \mathrm{kg}) \text { caused a rapid } \\
\text { decrease in the number of viable L. monocy- } \\
\text { togenes in the cheeses. }\end{array}$ & Brazil & [120] \\
\hline $\begin{array}{l}\text { Bacteriocine- } \\
\text { like E204 }\end{array}$ & $\begin{array}{l}\text { Enterococcus } \\
\text { durans E204 }\end{array}$ & $\begin{array}{l}\text { Camel } \\
\text { milk }\end{array}$ & $10^{6} \mathrm{cfu} \mathrm{ml}^{-1}$ & Jben & Listeria & $\begin{array}{l}\text { In jben batches prepared with E. Durans, } \\
\text { Listeria counts decreased progressively from } \\
\text { the beginning of storage and were unde- } \\
\text { tectable at } 8 \text { and } 6 \text { days post-contamination } \\
\text { with } 10^{6} \text { and } 10^{4} \mathrm{CFU} / \mathrm{ml} \text {, respectively. }\end{array}$ & Morocco & {$[85]$} \\
\hline $\begin{array}{l}\text { Enterocin } \\
\text { AS-48 }\end{array}$ & $\begin{array}{l}\text { Enterococcus } \\
\text { faecalis } \\
\text { UGRA10 }\end{array}$ & Not cited & $\begin{array}{c}100,50, \text { and } \\
25 \mathrm{\mu g} \mathrm{ml}^{-1}\end{array}$ & Rainbow & $\begin{array}{c}\text { Lactococcus } \\
\text { garvieae }\end{array}$ & $\begin{array}{l}\text { In broth cultures, enterocin at } 100,50 \text {, and } \\
25 \mu \mathrm{g} / \mathrm{ml} \text { reduced } 10^{8} \mathrm{CFU} / \mathrm{ml} \text { lactococci } \\
\text { after } 2,5 \text {, and } 10 \mathrm{~h} \text {, respectively. In co-cul- } \\
\text { tures of UGRA10/ Lactococcus garvieae at a } \\
1 / 10 \mathrm{CFU} / \mathrm{ml} \text { ratio, lactococci were elimi- } \\
\text { nated after } 24 \mathrm{~h} \text {. }\end{array}$ & Spain & [98] \\
\hline Not cited & $\begin{array}{l}\text { Lactobacillus } \\
\text { plantarum } \\
\text { T8 et T13 }\end{array}$ & $\begin{array}{l}\text { Animaux } \\
\text { marins et } \\
\text { chou } \\
\text { fermenté }\end{array}$ & $10^{8} \mathrm{cfu} \mathrm{m}^{-1}$ & $\begin{array}{l}\text { White-leg } \\
\text { shrimp }\end{array}$ & - & $\begin{array}{l}\text { Lactobacillus plantarum T8 and T13, exerted } \\
\text { antimicrobial activities against all tested Vib- } \\
\text { rio isolates. T8 enhanced significant growth } \\
\text { and survival of shrimps after bath challenge } \\
\text { with XN9. }\end{array}$ & Vietnam & [97] \\
\hline Not cited & $\begin{array}{l}\text { Lactococcus } \\
\text { lactis spp. } \\
\text { Lactis } \\
\text { PTCC1336 }\end{array}$ & Not cited & $10^{6} \mathrm{CFU} \mathrm{ml}^{-1}$ & $\begin{array}{l}\text { Rainbow } \\
\text { trout fillets }\end{array}$ & $\begin{array}{l}\text { Psychrotrophic, } \\
\text { psychrophilic, } \\
\text { mesophilic } \\
\text { bacteria, molds } \\
\text { and yeasts }\end{array}$ & $\begin{array}{l}\text { The } 4 \% \text { supernatant and live bacteria were } \\
\text { more effective than that of } 2 \% \text { and control } \\
\text { ( } p<0.05 \text { ). The amounts of corrosive bacteria } \\
\text { in } 4 \% \text { and live cells in storage time were less } \\
\text { than human consumption limits ( } 7 \text { log cfug- } \\
\text { 1), whereas in control and } 2 \% \text { supernatant } \\
\text { treatments were more than that limits. }\end{array}$ & Iran & [121] \\
\hline Nisin F & $\begin{array}{l}\text { Lactococcus } \\
\text { lactis subsp. } \\
\text { Lactis F10 }\end{array}$ & Not cited & $1280 \mathrm{AU} \mathrm{ml}^{-1}$ & $\begin{array}{l}\text { Respira- } \\
\text { tory } \\
\text { tract } \\
\text { infections }\end{array}$ & $\begin{array}{c}\text { Staphylococcus } \\
\text { aureus }\end{array}$ & $\begin{array}{l}\text { Nisin F inhibited the growth of Staphylococcus } \\
\text { aureus K in the respiratory tract of immuno- } \\
\text { compromised rats. Treatment with nisin F at } \\
8192 \mathrm{AU} \text { proofed safe, as the trachea, lungs, } \\
\text { bronchi and haematology of the rats } \\
\text { appeared normal. }\end{array}$ & $\begin{array}{l}\text { South } \\
\text { Africa }\end{array}$ & [108] \\
\hline Not cited & $\begin{array}{l}\text { Lactobacillus } \\
\text { salivarius } \\
\text { LSO3 }\end{array}$ & Not cited & $\begin{array}{l}\text { LSO3-soaked } \\
\text { disks }\end{array}$ & $\begin{array}{c}\text { Acne } \\
\text { therapy }\end{array}$ & $\begin{array}{l}\text { Propionibacterium } \\
\text { acnes }\end{array}$ & $\begin{array}{l}\text { Lactobacillus Salivarius Is03 exerted a signifi- } \\
\text { cant inhibitory capacity against the target } \\
\text { pathogen strain. This antagonistic activity } \\
\text { was primarily ascribable to the feature of } \\
\text { Is03 strain of secreting active bacteriocins } \\
\text { against Propionibacteriumacnes. Concerning } \\
\text { the il- } 8 \text { analysis, } 3 \text { different Lactobacillus } \\
\text { Salivarius strains were able to inhibit the } \\
\text { release of this chemokine by } 10 \% \text { to } 25 \%\end{array}$ & Italy & [107] \\
\hline Nisin nisaplin ${ }^{\circledast}$ & Not cited & $\begin{array}{l}\text { (Nisaplin }^{\oplus} \\
\text { from } \\
\text { Danisco, } \\
\text { Copenhagen, } \\
\text { Denmark }\end{array}$ & $15 \mathrm{mg} \mathrm{ml}^{-1}$ & $\begin{array}{l}\text { Biofilm } \\
\text { formation }\end{array}$ & $\begin{array}{l}\text { Staphylococcus } \\
\text { aureus Xen 31, } \\
\text { Xen 30, Xen } \\
36 \text { and Xen } 29\end{array}$ & $\begin{array}{l}\text { Biofilm formation decreased by } 88 \% \text { after } \\
24 \text { h of exposure to nanofibers containing } \\
\text { nisin and DHBA (NDF), compared to a } 63 \% \\
\text { decrease when exposed to nanofibers con- } \\
\text { taining only DHBA (DF) and a } 3 \% \text { decrease } \\
\text { when exposed to nanofibers containing } \\
\text { only nisin (NF). }\end{array}$ & $\begin{array}{l}\text { South } \\
\text { Africa }\end{array}$ & [122] \\
\hline
\end{tabular}


Table 2. Continued.

\begin{tabular}{|c|c|c|c|c|c|c|c|c|}
\hline Bacteriocin & Producer & Origin & Concentration & Product & Target & Properties & Country & Reference \\
\hline Nisin ZP & Not cited & $\begin{array}{l}\text { Handary } \\
\text { (s.a., brussels, } \\
\text { belgium) }\end{array}$ & $2.5-50 \mu \mathrm{g} \mathrm{ml}^{-1}$ & $\begin{array}{c}\text { Oral } \\
\text { cavity }\end{array}$ & $\begin{array}{l}\text { Streptococcus } \\
\text { oralis 3, } \\
\text { Streptococcus } \\
\text { mutans UA159 } \\
\text { and others }\end{array}$ & $\begin{array}{l}\text { Nisin inhibited planktonic growth of oral bacteria } \\
\text { at low concentrations }(2.5-50 \mu \mathrm{g} / \mathrm{ml}) \text {, and also } \\
\text { retarded development of multi-species biofilms } \\
\text { at concentrations } \geq 1 \mu \mathrm{g} / \mathrm{ml} \text {. }\end{array}$ & USA & [123] \\
\hline Nisin & $\begin{array}{l}\text { Lactococcus } \\
\text { lactis subsp. } \\
\qquad \text { Lactis } \\
\text { ATCC11454 }\end{array}$ & Not cited & $\begin{array}{l}100,300,900 \\
\text { et } 2700 \mathrm{IU} \mathrm{g}^{-1}\end{array}$ & $\begin{array}{c}\text { Broiler } \\
\text { chickens }\end{array}$ & - & $\begin{array}{l}\text { Dietary nisin exerts a mode of action similar to } \\
\text { salinomycin and could be considered as a dietary } \\
\text { supplement for broiler chickens. Nisin supple- } \\
\text { mentation improved broiler growth performance } \\
\text { in a dose-dependent manner. }\end{array}$ & Polande & [87] \\
\hline $\begin{array}{l}\text { Bactério- } \\
\text { cine LABW4 }\end{array}$ & $\begin{array}{l}\text { Lactococcus } \\
\text { lactis subsp. } \\
\text { Lactis LABW4 }\end{array}$ & $\begin{array}{l}\text { Fermented } \\
\text { milk }\end{array}$ & $\begin{array}{c}10 \% \text { de CFS } \\
\text { LABW4 }\end{array}$ & Meat & $\begin{array}{l}\text { L. } \\
\text { monocytogenes }\end{array}$ & $\begin{array}{l}\text { Both cell free and heat killed supernatants of } \\
\text { LABW4 were effective to produce zones of inhibi- } \\
\text { tion against } L \text {. monocytogenes in vitro. }\end{array}$ & India & [124] \\
\hline Paracin C & $\begin{array}{l}\text { Lactobacillus } \\
\text { paracasei } \\
\text { CICC } 20241\end{array}$ & $\begin{array}{l}\text { China Center } \\
\text { of Industrial } \\
\text { Culture } \\
\text { Collection, } \\
\text { China }\end{array}$ & $\begin{array}{c}20,50,100 \text {, } \\
\text { et } 200 \mathrm{Mg} \mathrm{ml}^{-1}\end{array}$ & $\begin{array}{l}\text { Apple } \\
\text { juice }\end{array}$ & A. Acidoterrestris & $\begin{array}{l}\text { Paracin C produced by Lactobacillus paracasei } \\
\text { CICC } 20241 \text { is a safe and efficient bacteriocin } \\
\text { active against } A \text {. Acidoterrestris. It is able to inhibit } \\
\text { and kill the cells of } A \text {. Acidoterrestris present in } \\
\text { apple juice and has a broad activity spectrum. }\end{array}$ & China & [94] \\
\hline $\begin{array}{l}\text { Lactococcin } \\
\qquad \mathrm{bz} \\
\text { enterocin kp }\end{array}$ & $\begin{array}{l}\text { L. Lactis spp. } \\
\text { Lactis bz } \\
\quad \text { and } \\
\text { e. Faecalis kp }\end{array}$ & & $\begin{array}{l}400 \mathrm{AU} \mathrm{m}^{-1} \\
400 \mathrm{AU} \mathrm{m}^{-1}\end{array}$ & Milk & $\begin{array}{l}\text { L. } \\
\text { monocytogenes } \\
\text { mats }\end{array}$ & $\begin{array}{l}\text { Lactococcin BZ at } 400-2500 \mathrm{AU} \mathrm{m}{ }^{-1} \text { level dis- } \\
\text { played strong antilisterial activity, and decreased } \\
\text { the viable cell numbers of } L \text {. monocytogenes to an } \\
\text { undetectable level in all types of milk samples } \\
\text { during the entire storage periods at } 4^{\circ} \mathrm{C} \text { or } 20^{\circ} \mathrm{C} \text {. }\end{array}$ & Turkey & [125] \\
\hline Nisin & $\begin{array}{l}\text { Lactococcus } \\
\text { lactis N5764 }\end{array}$ & & $\begin{array}{c}(1 / 4) 110 \mu \mathrm{g} \\
\mathrm{ml}^{-1} \\
(1 / 4) 125 \mu \mathrm{g} \\
\mathrm{ml}^{-1}\end{array}$ & Cow milk & $\begin{array}{l}\text { Staphylococcus } \\
\text { aureus ATCC } \\
25923 \text { and } \\
\text { Listeria monocyto } \\
\text { genes ATCC } \\
15313\end{array}$ & $\begin{array}{l}\text { The study aimed to investigate the antibacterial } \\
\text { activities of carvacrol, thymol, eugenol, cinnamal- } \\
\text { dehyde, and lantibiotic nisin. Inhibitory activities } \\
\text {-of nisin and the tested compounds, as well as } \\
\text { synergism in the combinations, were found } \\
\text { against Staphylococcus aureus ATCC } 25923 \text { and } \\
\text { Listeria monocytogenes ATCC } 15313 \text { in cow milk. }\end{array}$ & Brazil & [80] \\
\hline
\end{tabular}

age in a target strain of L. monocytogenes [127]. Another study investigated the antibacterial activity of nisin combined with phenolic compounds against Staphylococcus aureus and L. monocytogenes in cow's milk (Table 2), the study showed bacteriostatic effects of nisin combined with the different phenolic compounds tested, with a significant difference in the reduction of $L$. monocytogenes compared to control tests.

The effect of nisin combined in inhibiting biofilm formation was illustrated by the research of [122], in which biofilm formation was reduced by $88 \%$ after $24 \mathrm{~h}$ of exposure to biofilms nanofibers containing nisin and 2.3dihydroxybenzoic (DHBA), compared to a $63 \%$ decrease due to exposure to nanofibers containing only DHBA (Table 2).

It has been shown that a very delayed latency phase was apparent in the growth curves, when nisin $\mathrm{V}$ at $0.02 \%$ was combined with essential oils tested, compared to the nisin A equivalent [128].

On the other hand, combinations of bacteriocins and antibiotics can reduce the concentration of antibiotics needed to kill a target pathogen, thereby decreasing the risk of adverse side effects associated with the antibiotic.

In a study by [129], nisin interacted synergistically with several antibiotics and these combinations were effective against staphylococci biofilms. Thus, nisin was effective when used with polymyxins against Pseudomonas aeruginosa biofilms [130].

A recent study of [131] showed that durancin 61A, a broad-spectrum bacteriocin combined with antibiotics, were highly synergistic inhibitors of multidrug-resistant pathogens of clinical interest (S. aureus, C. difficile and Streptococcus spp.). With regard to Gram-negative germs, researchers were able to show a synergy of nisin combined with polymyxin B against Acinetobacter spp. and Escherichia coli. 
Bacteriocins are usually recognized as safe because they are sensitive to digestive proteases, not toxic to eukaryotic cells and have generally bactericidal antimicrobial potency. Their antimicrobial spectrum can be wide or narrow, so they can selectively target pathogenic or damaging bacteria without inhibiting essential bacteria.

The bacteriocins of lactic acid bacteria find their use in different fields where they prevent the development of pathogenic and harmful bacteria. In the field, the foods are either supplemented with bacteria producing bacteriocin, purified or semi-purified bacteriocin.

\section{Conflict of Interest}

The authors have no financial conflicts of interest to declare.

\section{References}

1. Moumene H, Hasib A, Soumia A, Jaouad A. 2013. Qualité Hygiénique des olives de table vendus en vrac dans la région Marrakech-Tensift El Hawz. Technol. Labo. 8: 32.

2. Amund OD. 2016. Exploring the relationship between exposure to technological and gastrointestinal stress and probiotic functional properties of lactobacilli and bifidobacteria. Can. J. Microbiol. 62: 715-725.

3. Hegarty JW, Guinane CM, Ross RP, Hill C, Cotter PD. 2016. Bacteriocin production: a relatively unharnessed probiotic trait? F1000Res. 5: 2587.

4. Heperkan D. 2013. Microbiota of table olive fermentations and criteria of selection for their use as starters. Front. Microbiol. 4: 143.

5. Bleve G, Tufariello M, Durante M., Perbellini E, Ramires FA, Grieco F, et al. 2014. Physico-chemical and microbiological characterization of spontaneous fermentation of Cellina di Nardò and Leccino table olives. Front. Microbiol. 5: 570.

6. Hurtado A, Reguant C, Bordons A, Rozès N. 2012. Lactic acid bacteria from fermented table olives. Food Microbiol. 31: 1-8.

7. Hati S, Mandal S, Prajapati JB. 2013. Novel starters for value added fermented dairy products. Curr. Res. Nutr. Food Sci. J. 1: 83-91.

8. Klaenhammer TR. 1988. Bacteriocins of lactic acid bacteria. Biochimie 70: 337-349.

9. Rubia-Soria A, Abriouel H, Lucas R, Omar NB, Martínez-Cañamero M, Gálvez A. 2006. Production of antimicrobial substances by bacteria isolated from fermented table olives. World J. Microbiol. Biotechnol. 22: 765-768.

10. Blana VA, Polymeneas N, Tassou CC, Panagou EZ. 2016. Survival of potential probiotic lactic acid bacteria on fermented green table olives during packaging in polyethylene pouches at 4 and 20 C. Food Microbiol. 53: 71-75.

11. El-Issaoui K, Zinebi S, Abrini J, Zahli R, Amajoud N, Senhaji NS, et al. 2017. Characterization of antibacterial lactic acid bacteria isolated from Moroccan fermented olives. Biosci. Biotechnol. Res. Asia 14: 1315.

12. López-Cuellar $M$, del $R$, Rodríguez-Hernández Al, ChavarríaHernández N. 2016. LAB bacteriocin applications in the last decade. Biotechnol. Biotechnol. Equip. 30: 1039-1050.

13. Van Reenen CA, Dicks LMT. 2011. Horizontal gene transfer amongst probiotic lactic acid bacteria and other intestinal microbiota: what are the possibilities. A review. Arch. Microbiol. 193: $157-168$.

14. Orla-Jensen S. 1919. "The lactic acid bacteria, Copenhagen. Andr" Fred Host Son.

15. Dellaglio F, De Roissart H, Torriani S, Curk MC, Janssens D. 1994. Caractéristiques générales des bactéries lactiques. Bactéries Lact. 1: 25-116.

16. Abriouel H, Benomar N, Cobo A, Caballero N, Fuentes MÁF, Pérez-Pulido R, et al. 2012. Characterization of lactic acid bacteria from naturally-fermented Manzanilla Aloreña green table olives. Food Microbiol. 32: 308-316.

17. Audisio MC, Apella MC. 2010. Bacteriocin-like substance produced by Lactobacillus salivarius subsp. salivarius CRL1384 with anti-Listeria and anti-Salmonella effects. Res. J. Microbiol. 5: 332340.

18. Matamoros S. Université de Nantes, 2008. Caractérisation de bactéries lactiques psychrotrophes en vue de leur utilisation dans la biopréservation des aliments. Étude physiologique et moléculaire des mécanismes d'adaptation au froid. Archimer 16: 148- 189.

19. Calo-Mata P, Arlindo S, Boehme K, de Miguel T, Pascoal A, Barros-Velazquez J. 2008. Current applications and future trends of lactic acid bacteria and their bacteriocins for the biopreservation of aquatic food products. Food Bioprocess Technol. 1: 43-63.

20. Liu JY, Li AH, Ji C, Yang WM. 2009. First description of a novel Weissella species as an opportunistic pathogen for rainbow trout Oncorhynchus mykiss (Walbaum) in China. Vet. Microbiol. 136: 314-320.

21. Khalid K. 2011. An overview of lactic acid bacteria. Int. J. Biosci. 1: 1-13.

22. Walter J. 2008. Ecological role of lactobacilli in the gastrointestinal tract: implications for fundamental and biomedical research. Appl. Environ. Microbiol. 74: 4985-4996.

23. Patrignani F, Serrazanetti DI, Mathara JM, Siroli L, Gardini F, Holzapfel WH, et al. 2016. Use of homogenisation pressure to improve quality and functionality of probiotic fermented milks containing Lactobacillus rhamnosus BFE 5264. Int. J. Dairy Technol. 69: 262-271.

24. Kandler O. 1983. Carbohydrate metabolism in lactic acid bacteria. Antonie. Van Leeuwenhoek 49: 209-224.

25. Gänzle MG. 2015. Lactic metabolism revisited: metabolism of lactic acid bacteria in food fermentations and food spoilage. Curr. Opin. Food Sci. 2: 106-117.

26. Gänzle MG, Vermeulen N. Vogel RF. 2007. Carbohydrate, peptide and lipid metabolism of lactic acid bacteria in sourdough. 
Food Microbiol. 24: 128-138.

27. World health organization, (WHO). 1-4 October 2001. Health and nutritional properties of probiotics in food including powder milk with live lactic acid bacteria, a joint FAO/WHO expert consultation. Cordoba, Argentina. http://www. who. int/foodsafety/publications/fs_management/probiotics/en/index.html./ 1-4 October 2001.

28. Gomez-Gil B, Roque A, Turnbull JF. 2000. The use and selection of probiotic bacteria for use in the culture of larval aquatic organisms. Aquaculture 191: 259-270.

29. Wang YB, Han JZ. 2007. The role of probiotic cell wall hydrophobicity in bioremediation of aquaculture. Aquaculture 269: 349-354.

30. Bermudez-Brito M, Plaza-Díaz J, Muñoz-Quezada S, GómezLlorente C, Gil A. 2012. Probiotic mechanisms of action. Ann. Nutr. Metab. 61: 160-174.

31. Wan LYM, Chen ZJ, Shah NP, El-Nezami H. 2016. Modulation of intestinal epithelial defense responses by probiotic bacteria. Crit. Rev. Food Sci. Nutr. 56: 2628-2641.

32. Piquepaille C. 1987. Place des probiotiques dans le traitement de diverses pathologies intestinales. 8: 1674-1678.

33. De Souza Barbosa M, Todorov SD, Ivanova I, Chobert JM, Haertlé T, de Melo Franc BDG. 2015. Improving safety of salami by application of bacteriocins produced by an autochthonous Lactobacillus curvatus isolate. Food Microbiol. 46: 254-262.

34. Butel MJ. 2014. Probiotics, gut microbiota and health. Méd. Mal. Infect. 44: 1-8.

35. Montoro BP, Benomar N, Lavilla Lerma L, Castillo Gutiérrez S, Gálvez A, Abriouel H. 2016. Fermented Aloreña table olives as a source of potential probiotic Lactobacillus pentosus strains. Front. Microbiol. 7: 1583.

36. Gratia A. 1925. Sur un remarquable exemple d'antagonisme entre deux souches de coilbacille. C.R. Soc. Biol. 93:1040-1042.

37. Hammami R, Zouhir A, Le Lay C, Hamida JB, Fliss I. 2010. Bactibase second release: a database and tool platform for bacteriocin characterization. BMC Microbiol. 10: 22.

38. Camargo AC, de Paula OAL, Todorov SD, Nero LA. 2016. In vitro evaluation of bacteriocins activity against Listeria monocytogenes biofilm formation. Appl. Biochem. Biotechnol. 178: 12391251.

39. Fox PF, Guinee TP, Cogan TM, McSweeney P. 2000. Fundamentals of Cheese Science. Aspen Publication, 638 p. Gauthersburg (Maryland, USA). ISBN 0-8342-1260-9.

40. De Freire Bastos MC, Coelho MLV, Da Silva Santos OC. 2015. Resistance to bacteriocins produced by Gram-positive bacteria. Microbiology 161: 683-700.

41. Zacharof MP, Lovitt RW. 2012. Bacteriocins produced by lactic acid bacteria a review article. APCBEE Procedia 2: 50-56.

42. Klaenhammer TR. 1988. Bacteriocins of lactic acid bacteria. Biochimie 70: 337-349.

43. Cotter PD, Ross RP, Hill C. 2013. Bacteriocins - a viable alternative to antibiotics? Nat. Rev. Microbiol. 11: 95-105.

44. Alvarez-Sieiro P, Montalbán-López M, Mu D, Kuipers OP. 2016.
Bacteriocins of lactic acid bacteria: extending the family. Appl. Microbiol. Biotechnol. 100: 2939-2951.

45. Bierbaum G, Sahl HG. 2009. Lantibiotics: mode of action, biosynthesis and bioengineering. Curr. Pharm. Biotechnol. 10: 2-18.

46. Arnison PG, Bibb MJ, Bierbaum G, Bowers AA, Bugni TS, Bulaj G, Cotter PD. 2013. Ribosomally synthesized and post-translationally modified peptide natural products: overview and recommendations for a universal nomenclature. Nat. Prod. Rep. 30: 108-160.

47. Dierksen KP, Inglis M, Tagg JR. 2000. High pharyngeal carriage rates of Streptococcus pyogenes in Dunedin school children with a low incidence of rheumatic fever. N. Z. Med. J. 113: 496499.

48. McAuliffe O, Ross RP, Hill C. 2001. Lantibiotics: structure, biosynthesis and mode of action. FEMS Microbiol. Rev. 25: 285-308.

49. Avonts L, De LV. 2001. Antimicrobial potential of probiotic lactic acid bacteria. Meded. Rijksuniv. Te Gent Fak. Landbouwkd. En Toegep. Biol. Wet. 66: 543-550.

50. Fimland G, Johnsen L, Dalhus B, Nissen-Meyer J. 2005. Pediocin-like antimicrobial peptides (class lla bacteriocins) and their immunity proteins: biosynthesis, structure, and mode of action. J. Pept. Sci. 11: 688-696.

51. Oppegård C, Rogne $P$, Emanuelsen $L$, Kristiansen $P E$, Fimland $G$, Nissen-Meyer J. 2007. The two-peptide class II bacteriocins: structure, production, and mode of action. J. Mol. Microbiol. Biotechnol. 13: 210-219.

52. Cotter PD, Hill C, Ross RP. 2005. Bacteriocins: developing innate immunity for food. Nat. Rev. Microbiol. 3: 777-388.

53. Lazdunski CJ. 1995. Colicin import and pore formation: a system for studying protein transport across membranes? Mol. Microbiol. 16: 1059-1066.

54. Riley MA. 1993. Molecular mechanisms of colicin evolution. Mol. Biol. Evol. 10: 1380-1395.

55. Balakrishnan M, Simmonds RS, Tagg JR. 2000. Dental caries is a preventable infectious disease. Aust. Dent. J. 45: 235-245.

56. Tomás MS J, Ocaña VS, Nader-Macías ME. 2004.Viability of vaginal probiotic lactobacilli during refrigerated and frozen storage. Anaer. 10: 1-5.

57. Vignolo GM, de Kairuz MN, de Ruiz Holgado AA, Oliver G. 1995. Influence of growth conditions on the production of lactocin 705, a bacteriocin produced by Lactobacillus casei CRL 705. J. Appl. Bacteriol. 78: 5-10.

58. Zalán Z, Németh E, Baráth Á, Halász A. 2005. Influence of growth medium on hydrogen peroxide and bacteriocin production of Lactobacillus strains. Food Technol. Biotechnol. 43: 219-225.

59. Savijoki K, Ingmer H, Varmanen P. 2006. Proteolytic systems of lactic acid bacteria. Appl. Microbiol. Biotechnol. 71: 394-406.

60. Malheiros PS, Sant'Anna V, Todorov SD, Franco BD. 2015. Optimization of growth and bacteriocin production by Lactobacillus sakei subsp. sakei2a. Braz. J. Microbiol. 46: 825-834.

61. Arfani N, Nur F, Hafsan, Azrianingsih R. 2017, May. Bacteriocin production of Lactobacillus sp. from intestines of ducks (Anas 
domesticus $\mathrm{L}$.) incubated at room temperature and antibacterial effectivity against pathogen. In AIP Conference Proceedings (Vol. 1844, No. 1, p. 030004). AIP Publishing LLC.

62. Barman S, Ghosh R, Mandal NC. 2018. Production optimization of broad spectrum bacteriocin of three strains of Lactococcus lactis isolated from homemade buttermilk. Ann. Agrar. Sci. 16: 286-296.

63. Marwati T, Cahyaningrum N, Widodo S, Januarsyah T. 2018. January. Inhibitory activity of bacteriocin produced from Lactobacillus SCG 1223 toward L. monocytogenes, S. thypimurium and E. coli. IOP Conference Series: Earth Environ. Sci. 102: 012091.

64. Dortu C, Huch M, Holzapfel WH, Franz C, Thonart P. 2008. Anti-listerial activity of bacteriocin-producing Lactobacillus curvatus CWBI-B28 and Lactobacillus sakei CWBI-B1365 on raw beef and poultry meat. Lett. Appl. Microbiol. 47: 581-586.

65. Jasniewski J. 2008. Etude des mécanismes d'action de bactériocines de la sous-classe lia. Thèse de doctorat. pp.9-55. Laboratoire de Science et Génie Alimentaires, Nancy.

66. Dortu C, Thonart P. 2009. Les bactériocines des bactéries lactiques: caractéristiques et intérêts pour la bioconservation des produits alimentaires. Biotechnol. Agron. Société Environ. 13: 143-154.

67. And HC, Hoover DG. 2003. Bacteriocins and their food applications. Compr. Rev. Food Sci. Food Saf. 2: 82-100.

68. Fath MJ, Kolter R. 1993. ABC transporters: bacterial exporters. Microbiol. Rev. 57: 995-1017.

69. Guyonnet D, Fremaux C, Cenatiempo Y, Berjeaud JM. 2000. Method for rapid purification of class lla bacteriocins and comparison of their activities. Appl. Environ. Microbiol. 66: 17441748.

70. Bauer R, Dicks LMT. 2005. Mode of action of lipid II-targeting lantibiotics. Int. J. Food Microbiol. 101: 201-216.

71. Taale E, Savadogo A, Zongo C, Tapsoba F, Karou SD, Traore AS. 2016. Les peptides antimicrobiens d'origine microbienne: cas des bactériocines. Int. J. Biol. Chem.Sci. 10: 384-399.

72. Breukink E, De Kruijff B. 2006. Lipid II as a target for antibiotics. Nat. Rev. Drug Discov. 5: 321-332.

73. Makhloufi KM. 2011. Caractérisation d'une bactériocine produite par une bactérie lactique Leuconostoc pseudomesenteroides isolée du boza (Doctoral dissertation).

74. Patton GC, Van Der Donk WA. 2005. New developments in lantibiotic biosynthesis and mode of action. Curr. Opin. Microbiol. 8: 543-551.

75. Nilsen T, Nes IF, Holo H. 2003. Enterolysin A, a cell wall-degrading bacteriocin from Enterococcus faecalis LMG 2333. Appl. Environ. Microbiol. 69: 2975-2984.

76. Dicks LMT, Heunis TDJ, Van Staden DA, Brand A, Noll KS, Chikindas ML. 2011. Medical and personal care applications of bacteriocins produced by lactic acid bacteria. In Prokaryotic Antimicrobial Peptides, pp. 391-421. Springer, New York, NY.

77. Sánchez-Hidalgo M, Montalbán-López M, Cebrián R, Valdivia $E$, Martínez-Bueno M, Maqueda M. 2011. AS-48 bacteriocin: close to perfection. Cell. Mol. Life Sci. 68: 2845-2857.
78. Suda S, Cotter PD, Hill C, Paul Ross R. 2012. Lacticin 3147-biosynthesis, molecular analysis, immunity, bioengineering and applications. Curr. Protein Pept. Sci. 13: 193-204.

79. Fangio MF, Fritz R. 2014. Potential use of a bacteriocin-like substance in meat and vegetable food biopreservation. Int. Food Res. J. 21: 677.

80. Alves FC, Barbosa LN, Andrade BF, Albano M, Furtado FB, Pereira AFM, et al. 2016. Inhibitory activities of the lantibiotic nisin combined with phenolic compounds against Staphylococcus aureus and Listeria monocytogenes in cow milk. J. Dairy Sci. 99: 1831-1836.

81. Ribeiro SC, Ross RP, Stanton C, Silva CC. 2017. Characterization and application of antilisterial enterocins on model fresh cheese. J. Food Prot. 80: 1303-1316.

82. Kondrotiene K, Kasnauskyte N, Serniene L, Gölz G, Alter T, Kaskoniene V, et al. 2018. Characterization and application of newly isolated nisin producing Lactococcus lactis strains for control of Listeria monocytogenes growth in fresh cheese. LWT. 87: 507-514.

83. Sarantinopoulos $P$, Leroy $F$, Leontopoulou E, Georgalaki MD, Kalantzopoulos G, Tsakalidou E, et al. 2002. Bacteriocin production by Enterococcus faecium FAIR-E 198 in view of its application as adjunct starter in Greek Feta cheese making. Int. J. Food Microbiol. 72: 125-136.

84. Beshkova D, Frengova G. 2012. Bacteriocins from lactic acid bacteria: microorganisms of potential biotechnological importance for the dairy industry. Eng. Life Sci. 12: 419-432.

85. El Moussaoui N, Idaomar M, Abrini J. 2014. Application of a bacteriocin-like inhibitory substance producing Enterococcus durans E204 strain, isolated from camel milk, to control Listeria monocytogenes CECT 4032 in goat jben. Ann. Microbiol. 64: 313-319.

86. Rogers LA. 1928. The inhibiting effect of Streptococcus lactis on Lactobacillus bulgaricus. J. Bacteriol. 16: 321-325.

87. Józefiak D, Kierończyk B, Juśkiewicz J, Zduńczyk Z, Rawski M, Długosz J, et al. 2013. Dietary nisin modulates the gastrointestinal microbial ecology and enhances growth performance of the broiler chickens. PLoS One 8: e85347.

88. Huang E, Zhang L, Chung YK, Zheng Z, Yousef AE. 2013. Characterization and application of enterocin RM6, a bacteriocin from Enterococcus faecalis. Biomed. Res. Int. 2013: 206917.

89. De Lima Marques J, Funck GD, Da Silva Dannenberg G, Dos Santos Cruxen CE, El Halal SLM, et al. 2017. Bacteriocin-like substances of Lactobacillus curvatus P99: characterization and application in biodegradable films for control of Listeria monocytogenes in cheese. Food Microbiol. 63: 159-163.

90. Xie Y, Zhang M, Gao X, Shao Y, Liu H, Jin J, et al. 2018. Development and antimicrobial application of plantaricin BM-1 incorporating a PVDC film on fresh pork meat during cold storage. J. App. Microbiol. 125: 1108-1116.

91. Hotchkiss JH. 1997. Food-packaging interactions influencing quality and safety. Food Addit. Contam. 14: 601-607.

92. Padgett T, Han IY, Dawson PL. 1998. Incorporation of food- 
grade antimicrobial compounds into biodegradable packaging films. J. Food Prot. 61: 1330-1335.

93. Deegan LH, Cotter PD, Hill C, Ross P. 2006. Bacteriocins: biological tools for bio-preservation and shelf-life extension. Int. Dairy J. 16: 1058-1071.

94. Pei J, Yue T, Yuan Y, Dai L. 2017. Activity of paracin C from lactic acid bacteria against Alicyclobacillus in apple juice: Application of a novelty bacteriocin. J. Food Saf. 37: e12350.

95. Wayah SB, Philip K. 2018. Characterization, yield optimization, scale up and biopreservative potential of fermencin SA715, a novel bacteriocin from Lactobacillus fermentum GA715 of goat milk origin. Microb. Cell Fact. 17: 125.

96. Mohammadian T, Alishahi M, Tabandeh MR, Ghorbanpoor M, Gharibi D, Tollabi M, Rohanizade S. 2016. Probiotic effects of Lactobacillus plantarum and L. delbrueckii ssp. bulguricus on some immune-related parameters in Barbus grypus. Aquac. Intern. 24: 225-242.

97. Nguyen TTG, Nguyen TC, Leelakriangsak M, Pham TT, Pham $\mathrm{QH}$, Lueangthuwapranit C, et al. 2018. Promotion of Lactobacillus plantarum on growth and resistance against acute hepatopancreatic necrosis disease pathogens in white-leg shrimp (Litopenaeus vannamei). Thai. J. Vet. Med. 48: 19-28.

98. Baños A, Ariza JJ, Nuñez C, Gil-Martínez L, García-López JD, Martínez-Bueno M, Valdivia E. 2019. Effects of Enterococcus faecalis UGRA10 and the enterocin AS-48 against the fish pathogen Lactococcus garvieae. Studies in vitro and in vivo. Food Microbiol. 77: 69-77.

99. Matsuura Y, Takasaki M, Miyazawa R, Nakanishi T. 2017. Stimulatory effects of heat-killed Enterococcus faecalis on cell-mediated immunity in fish. Dev. Comp. Immunol. 74: 1-9.

100. Wang YB, Tian ZQ, Yao JT, Li W. 2008. Effect of probiotics, Enteroccus faecium, on tilapia (Oreochromis niloticus) growth performance and immune response. Aquac. 277: 203-207.

101. Mkrtchyan H, Gibbons S, Heidelberger S, Zloh M, Limaki HK. 2010. Purification, characterisation and identification of acidocin LCHV, an antimicrobial peptide produced by Lactobacillus acidophilus nv Er 317/402 strain Narine. Int. J. Antimicrob. Agents. 35: 255-260.

102. Bastos MCF, Ceotto H, Coelho MLV, Nascimento JS. 2009. Staphylococcal antimicrobial peptides: relevant properties and potential biotechnological applications. Curr. Pharm. Biotechnol. 10: $38-61$.

103. Toualbia M, Bouras AED, Koiche M, Kerkoud M. 2018. Isolation, identification and characterization of Lactobacillus plantarum from camel milk and its antagonist effect against diarrheal bacteria. Emir. J. Food Agric. 283-287.

104. Sirichokchatchawan W, Temeeyasen G, Nilubol D. Prapasarakul N. 2018. Protective effects of cell-free supernatant and live lactic acid bacteria isolated from Thai pigs against a pandemic strain of porcine epidemic diarrhea virus. Probiotics Antimicrob. Proteins 10: 383-390.

105. Maldonado NC, Chiaraviglio J, Bru E, De Chazal L, Santos V, Nader-Macías MEF. 2018. Effect of milk fermented with lactic acid bacteria on diarrheal incidence, growth performance and microbiological and blood profiles of newborn dairy calves. Probiotics Antimicrob. Proteins 10: 668-676.

106. Ren C, Zhang Q, De Haan BJ, Zhang H, Faas MM, De Vos P. 2016. Identification of TLR2/TLR6 signalling lactic acid bacteria for supporting immune regulation. Sci. Rep. 6: 34561.

107. Deidda F, Amoruso A, Nicola S, Graziano T, Pane M, Mogna L. 2018. New approach in acne therapy: A specific bacteriocin activity and a targeted Anti IL-8 property in just 1 probiotic strain, the L. salivarius LS03. J. Clin. Gastroenterol. 52: S78-S81.

108. De Kwaadsteniet M, Doeschate KT, Dicks LMT. 2009. Nisin F in the treatment of respiratory tract infections caused by Staphylococcus aureus. Lett. Appl. Microbiol. 48: 65-70.

109. Van Staden DA, Brand AM, Endo A, Dicks LMT, Nisin F, 2011. Intraperitoneally injected, may have a stabilizing effect on the bacterial population in the gastro-intestinal tract, as determined in a preliminary study with mice as model. Lett. Appl. Microbiol. 53: 198-201.

110. De Gregorio PR, Tomás MSJ, Terraf MCL, Nader-Macías MEF. 2014. In vitro and in vivo effects of beneficial vaginal lactobacilli on pathogens responsible for urogenital tract infections. J. Med. Microbiol. 63: 685-696.

111. Rivas FP, Cayré ME, Campos CA, Castro MP. 2018. Natural and artificial casings as bacteriocin carriers for the biopreservation of meats products. J. Food Saf. 38: e12419.

112. Zhang J, Liu G, Li P, Qu Y. 2010. Pentocin 31-1, a novel meatborne bacteriocin and its application as biopreservative in chillstored tray-packaged pork meat. Food Control 21: 198-202.

113. Kato T, Maeda K, Kasuya H, Matsuda T. 1999. Complete growth inhibition of Bacillus subtilis by nisin-producing lactococci in fermented soybeans. Biosci. Biotechnol. Biochem. 63: 642-647.

114. Arief II, Wulandari Z, Sinaga ES, Situmorang DM. 2017. Application of Purified Bacteriocin from Lactobacillus plantarum IIA$1 \mathrm{~A} 5$ as a Bio-preservative of Beef Sausage. Pak. J. Nutr. 16: 444450.

115. Kaur B, Balgir PP, Mittu B, Kumar B, Garg N. 2013. Biomedical applications of fermenticin HV6b isolated from Lactobacillus fermentum HV6b MTCC10770. Biomed. Res. Int. 2013: 168438.

116. Van Doan H, Doolgindachbaporn S, Suksri A. 2016. Effects of Eryngii mushroom (Pleurotus eryngii) and Lactobacillus plantarum on growth performance, immunity and disease resistance of Pangasius catfish (Pangasius bocourti, Sauvage 1880). Fish Physiol. Biochem. 42: 1427-1440.

117. Lv X, Ma H, Sun M, Lin Y, Bai F, Li J, Zhang B. 2018. A novel bacteriocin DY4-2 produced by Lactobacillus plantarum from cutlassfish and its application as bio-preservative for the control of Pseudomonas fluorescens in fresh turbot (Scophthalmus maximus) fillets. Food Control 89: 22-31.

118. Grilli E, Messina MR, Catelli E, Morlacchini M, Piva A. 2009. Pediocin A improves growth performance of broilers challenged with Clostridium perfringens. Poult. Sci. 88: 2152-2158.

119. Safari R, Adel M, Lazado CC, Caipang CMA, Dadar M. 2016. Hostderived probiotics Enterococcus casseliflavus improves resis- 
tance against Streptococcus iniae infection in rainbow trout (Oncorhynchus mykiss) via immunomodulation. Fish Shellfish Immunol. 52: 198-205.

120. Furtado DN, Todorov SD, Landgraf M, Destro MT, Franco BD. 2015. Bacteriocinogenic Lactococcus lactis subsp. lactis DF04Mi isolated from goat milk: Application in the control of Listeria monocytogenes in fresh Minas-type goat cheese. Braz. J. Microbiol. 46: 201-206.

121. Anbi AA, Razavilar V, Naghadehi MN, Osalou YAA. 2018. The effects of Lactococcus lactis subsp. lactis and its supernatant on some bacteriological and sensory values in Rainbow trout (Onchorhynchus mykiss) fillets. Microbiol. Res. 9: 7431.

122. Ahire JJ, Dicks LM. 2015. Nisin incorporated with 2, 3-dihydroxybenzoic acid in nanofibers inhibits biofilm formation by a methicillin-resistant strain of Staphylococcus aureus. Probiotics Antimicrob. Proteins 7: 52-59.

123. Kapila Y, Shin JM, Ateia I, Paulus JR, Liu H, Fenno JC, et al. 2015. Antimicrobial nisin acts against saliva derived multi-species biofilms without cytotoxicity to human oral cells. Front. Microbiol. 6: 617.

124. Barman S, Ghosh R, Mandal NC. 2014. Use of bacteriocin producing Lactococcus lactis subsp. lactis LABW4 to prevent Listeria monocytogenes induced spoilage of meat. Food Nutr. Sci. 5: 2115.

125. Yildirim Z, Öncül N, Yildirim M, Karabiyikli Ş. 2016. Application of lactococcin BZ and enterocin KP against Listeria monocytogenes in milk as biopreservation agents. Acta Aliment. 45: 486492.

126. Drider D, Fimland G, Héchard Y, McMullen LM, Prévost H. 2006. The continuing story of class lla bacteriocins. Microbiol. Mol. Biol. Rev. 70: 564-582.

127. Sivarooban T, Hettiarachchy NS, Johnson MG. 2008. Transmission electron microscopy study of Listeria monocytogenes treated with nisin in combination with either grape seed or green tea extract. J. Food Prot. 71: 2105-2109.

128. Field D, Daly K, O'Connor PM, Cotter PD, Hill C, Ross RP. 2015. Efficacies of nisin $A$ and nisin $V$ semipurified preparations alone and in combination with plant essential oils for controlling Listeria monocytogenes. Appl. Environ. Microbiol. 81: 2762-2769.

129. Field D, O'Connor R, Cotter PD, Ross RP, Hill C. 2016. In vitro activities of nisin and nisin derivatives alone and in combination with antibiotics against Staphylococcus biofilms. Front. Microbiol. 7: 508.

130. Field D, Seisling N, Cotter PD, Ross RP, Hill C. 2016. Synergistic nisin-polymyxin combinations for the control of Pseudomonas biofilm formation. Front. Microbiol. 7: 1713.

131. Hanchi $H$, Hammami $R$, Gingras $H$, Kourda R, Bergeron MG, Ben Hamida J, et al. 2017. Inhibition of MRSA and of Clostridium difficile by durancin 61A: synergy with bacteriocins and antibiotics. Future Microbiol. 12: 205-212. 